\title{
Gnathia pantherina sp. n. (Crustacea: Isopoda: Gnathiidae), a temporary ectoparasite of some elasmobranch species from southern Africa
}

\author{
Nico J. Smit ${ }^{1,2}$ and Linda Basson ${ }^{1}$ \\ ${ }^{1}$ Department of Zoology and Entomology, University of the Free State, P.O. Box 339, Bloemfontein, 9300, South Africa; \\ ${ }^{2}$ Present address: School of Life Sciences, Kingston University, Penrhyn Road, Kingston upon Thames, Surrey, KT1 2EE, UK
}

Key words: Gnathiidae, Gnathia, description, morphology, parasite, Elasmobranchii

\begin{abstract}
Haematophagous larvae of a gnathiid isopod were collected from the gills, nares and buccal cavity of a single leopard catshark Poroderma pantherinum (Smith, 1838) at Jeffreys Bay and five puffadder shysharks Haploblepharus edwardsii (Voight, 1832) and one blackspotted electric ray Torpedo fuscomaculata Peters, 1855, at the De Hoop Nature Reserve on the South African south coast. Larvae were kept in fresh seawater until their moult into adult stages. The morphology of the adult males did not conform to that of any known species and they are therefore described as Gnathia pantherina sp. n. The descriptions of the adult male, female and praniza larva are based on light and scanning electron microscopy observations. Characteristic features of this species include the large size of all the final life-cycle stages, the deeply divided mediofrontal process of the male, the morphology of the pylopods and maxillipedes of the female, and the number of teeth on the mandibles (eight) and maxillules (seven) of the praniza larvae.
\end{abstract}

All current descriptions of gnathiid isopods are based on the morphology of free-living adult males. Most of these specimens have been found in sponges, on the ocean floor, associated with coral substratum, or, as in the case of Paragnathia formica (Hesse, 1864), in microcliffs of estuaries (see Monod 1926, Cohen and Poore 1994). In this paper, a species of gnathiid is described for the first time from adult males and females obtained from moulting pranizae found as parasites of elasmobranch hosts. This method of obtaining adult specimens enables the description of the male, female and larva, as well as allowing insight into gnathiids as parasites of some elasmobranch species. Several authors have documented gnathiid larvae from elasmobranchs (Barnard 1926, Monod 1926, Paperna and Por 1977, Honma and Chiba 1991, Honma et al. 1991, Grutter and Poulin 1998, Heupel and Bennett 1999). In some early descriptions of larvae, these were described as new species, i.e., Anceus rhinobatis Kossmann, 1877, Anceus torpedinis Walter, 1885, Gnathia aureola Stebbing, 1900 and Gnathia aldabrensis Scoenichen, 1908 (see Monod 1926). The re-identification of these gnathiids is almost impossible, since species descriptions should not be exclusively based on the morphology of the parasitic larvae.

\section{MATERIALS AND METHODS}

Material used in this study was collected during fieldwork in January 1999 at Jeffreys Bay and during April and October 1999 at the De Hoop Nature Reserve. A single live specimen of the leopard catshark, Poroderma pantherinum (Smith,
1838) was obtained from a local fisherman at Jeffreys Bay. At the De Hoop Nature Reserve five puffadder shysharks, Haploblepharus edwardsii (Voight, 1832) and a single blackspotted electric ray, Torpedo fuscomaculata Peters, 1855 were caught by means of hand nets in deep tidal pools during the evening low tide. In the field laboratory, fishes were killed using high concentrations $\left(2.5 \times 10^{-5} \mathrm{~g} / \mathrm{l}\right)$ of the anaesthetic benzocaine (ethyl-4-aminobenzoate), and then identified using Smith and Heemstra (1986), measured and subsequently examined for parasite infections. Live gnathiid larvae were removed from the hosts (Fig. 40) and their position and numbers were determined (Table 1). Only final-stage larvae were found. All larvae were kept alive in $50 \mathrm{ml}$ specimen jars filled with seawater in order for them to moult into adults. The adult males obtained through the moulting of the male larvae did not conform to the description of any known gnathiid males and are thus described as a new species along with the adult females and praniza larvae. This description follows the anatomical taxonomy, numbering of pereonites and pereopods, and general layout used by Cohen and Poore (1994), Smit and Van As (2000) and Smit et al. (2000).

\section{RESULTS}

Gnathia pantherina sp. n.

Adult male

Figs. 1-11, 33-37

Description: Total length of holotype: $5.6 \mathrm{~mm}$. Total length of paratypes: $4.9-6.1 \mathrm{~mm}(5.4 \pm 0.43 \mathrm{~mm}, \mathrm{n}=6)$. Total length of other material: $3.7-6.8 \mathrm{~mm}(5.4 \pm 1.0, \mathrm{n}$ $=13$ ).

CEPHAlOSOME. Rectangular, 1.4 times as wide as long, deep dorsal sulcus, narrower than width of median 
Table 1. Number and site of attachment of parasitic larvae of Gnathia pantherina sp. n. on the three species of elasmobranchs investigated. Abbreviations: $\mathrm{n}$ - number, $\mathrm{N}$ - nares, $\mathrm{BC}$ - buccal cavity, $\mathrm{G}$ - gills, $\mathrm{T}$ - total, $\mathrm{MB}$ - mean burden, $\mathrm{SD}$ - standard deviation.

\begin{tabular}{|l|c|c|c|c|c|c|c|}
\hline \multicolumn{3}{|c|}{ Hosts } & \multicolumn{6}{c|}{ Larvae } \\
Species & $\mathrm{n}$ & Length (mm) & $\mathrm{N}$ & $\mathrm{BC}$ & $\mathrm{G}$ & $\mathrm{T}$ & $\mathrm{MB} \pm$ SD (Range) \\
\hline Poroderma pantherinum & 1 & 580 & 0 & 0 & 34 & 34 & - \\
Torpedo fuscomaculata & 1 & 388 & 0 & 0 & 3 & 3 & - \\
Haploblepharus edwardsii & 5 & $448-620$ & 3 & 1 & 107 & 111 & $22 \pm 19.2(2-45)$ \\
\hline
\end{tabular}

process, extending half the length of cephalosome (Figs. 1,33 ), lateral margins convex, row of long pappose setae and tubercles extending laterally from under eyes posterio-medially almost reaching median tubercle (Figs. 3, 34), posterior margin concave (Fig. 1). Sensory pits, some with single short pappose seta, and short hairlike simple setae distributed randomly over dorsal and lateral surface of cephalosome (Figs. 33, 34), no sensory pits in dorsal sulcus. Pappose setae, sensory pits and short simple setae ventrally on lateral sides of buccal cavity. Well-developed oval-shaped, bulbous, sessile compound eyes on lateral margin of cephalosome, length of eye slightly less than third of cephalosome (Figs. 3, 34). Eight to ten paraocular tubercles with long pappose setae (Fig. 3). Elliptical posterior median tubercle present (Fig. 1).

FRONTAL BORDER. Slightly produced, superior frontolateral process conical, directed antero-laterally, with seven to nine long pappose setae on inner border (Figs. 2, 35). Mediofrontal process inferior, deeply divided into two acute lobes, no frontolateral process (Figs. 2, 35). Lamina dentata with eight to eleven tubercles visible (Fig. 2). External scissura shallow. Supraocular lobe not pronounced with eight to ten pappose setae and four to five tubercles dorsally.

ANTENNAE. Antenna 2 longer than antenna 1. Antenna 1 with three peduncle articles increasing in length distally with third article as long as first and second articles combined, all three peduncle articles covered with very short hair-like simple setae (Fig. 5). Flagellum with five articles, article 3 largest, articles 3 and 4 with one aesthetasc seta each, article 5 terminating in one aesthetasc and three simple setae, few setae on each article (Fig. 5). Antenna 2 with five peduncle articles covered with very short hair-like simple setae, article 4 and 5 largest, flagellum with seven articles, article 1 largest, article 7 terminating in five simple setae (Fig. 4).

MANDIBLE. Long, two-thirds length of cephalosome, twice as long as wide, broad basal neck, curved inwards with seven to eight processes on dentate blade, tussle of setae between processes (Fig. 36). Apex cylindrical, distally raised in lateral view. Slight incisor present. Single pappose mandibular seta extending from base of incisor process. Carina armed, forming ridge on lateral margin extending from basal neck to a third along mandible (Figs. 2, 36). Short simple hair-like setae distributed randomly on dorsal surface of blade. Internal lobe and pseudoblade absent.

PYLOPOD. Three articles. First article greatly enlarged, convex mesial border fringed with plumose setae, lateral and proximal setae short and simple, a pair of feather-like setae near lateral border and five pappose setae distally on posterior surface (Fig. 8). Single small areola. Second article oval, 1.5 times as long as wide, margins setose, six pappose setae distally on posterior surface (Fig. 9). Third article minute with fringing setae (Fig. 9).

MAXILLIPED. Five-articled, proximal article largest with slender mediodistal endite reaching article 3 (Fig. 10). Outer margin of proximal article densely setose. Distal four articles bearing plumose setae on lateral margins in order of 5-7-5-7, mesial border with short simple setae (Fig. 10). Distal article with four short simple setae. Palp 1.5 times as long as wide. No coupling hooks.

PEREON. One and a third times as long as wide, wider than cephalosome (Fig. 1), covered with numerous long pappose setae and short simple hair-like setae. Pereonite 1 fused with cephalosome, dorsally visible, not reaching lateral margins, anterior border convex, posterior margin slightly concave (Fig. 1). Pereonite 2 and 3 of similar size, widest part of body, lateral margins pointing anteriorly. Pereonite 4 with prominent anterior constriction separating it from pereonite 3 . Tubercles as well as long pappose setae on anterior lateral lobe of pereonite 4 , median groove present. Pereonite 5 with areae laterales and dorsal sulcus as thin groove. Pereonite 5 and 6 not fused. Pereonite 6 at least twice as long as other pereonites, 1.6 times as long as wide, posterior margin deeply concave, with lobi laterales, no lobuii. Pereonite 7 dorsally visible, small with rounded posterior margin, overlapping first pleonite. Long pappose setae on anterior, lateral and posterior margins of pereonites.

PLEON. Pleon and pleotelson less than third of total length (Fig. 1). Five subequal pleonites dorsally visible, epimera dorsally visible, long pappose setae randomly distributed on pleonites. 

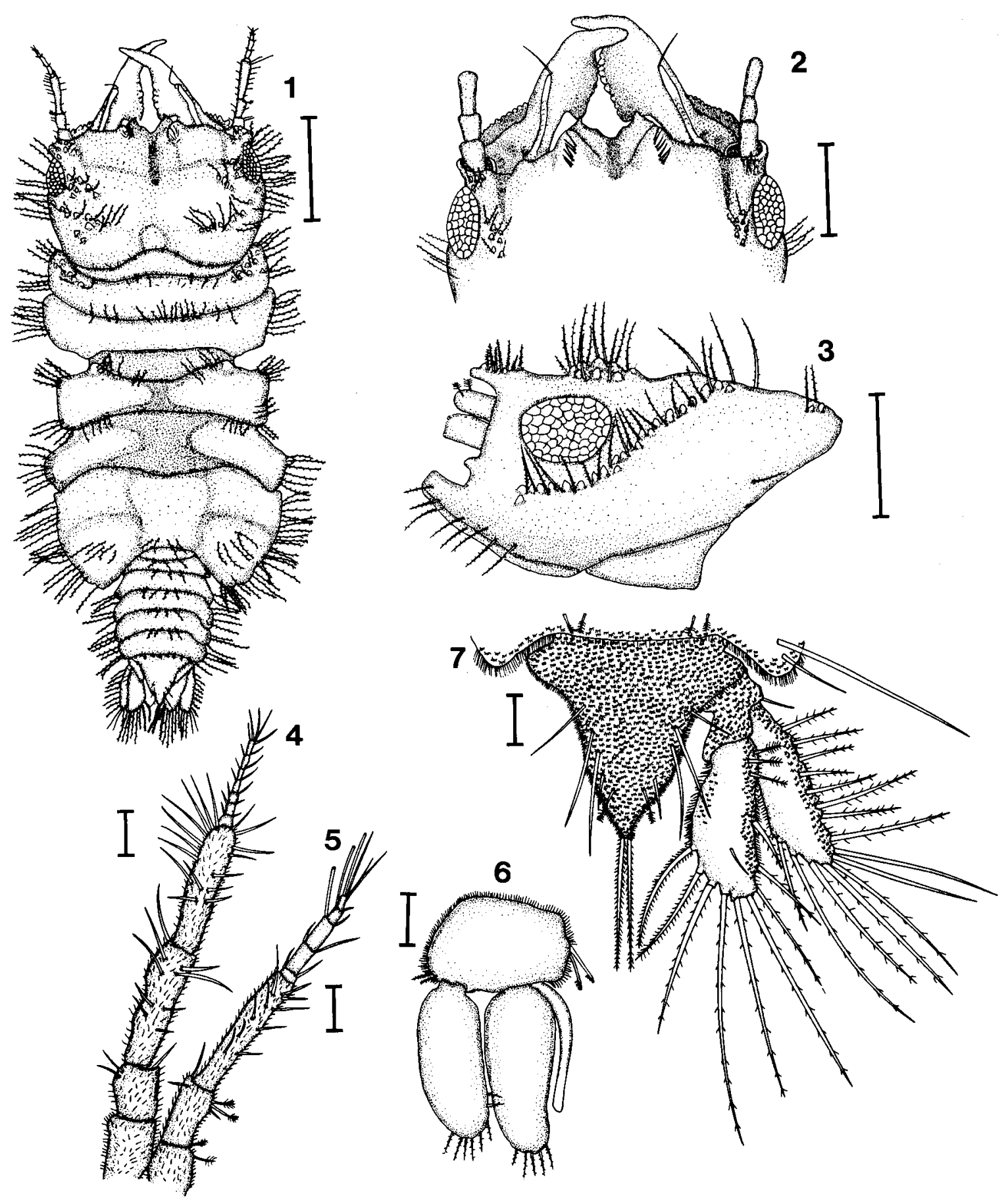

Figs. 1-7. Gnathia pantherina sp. n., male (NMBP 216). Fig. 1. Full length dorsal view. Fig. 2. Frontal border and mandibles. Fig. 3. Lateral view of cephalosome. Fig. 4. Second antenna. Fig. 5. First antenna. Fig. 6. Left pleopod 2 with appendix masculina. Fig. 7. Pleotelson and uropods. Scale bars: Fig. $1=1 \mathrm{~mm}$; Figs. 2, $3=500 \mu \mathrm{m}$; Figs. 4-7 = $100 \mu \mathrm{m}$.

PLEOTELSON. Triangular, base wider than length, lateral margins slightly concave, dorsal surface with four pairs of long pappose setae and proximal pair of feather-like setae, many pectinate scales on dorsal surface, distal apex terminating in pair of pappose setae (Fig. 7).
PEREOPODS. Pereopod 2 basis elongated, oval-shaped with 10 to 12 pappose setae and feather-like setae anterior, five to eight posterior pappose setae (Fig. 11). Ischium two thirds length of basis, three to five anterior setae, posterior tubercles with simple and pappose setae in between. Merus half the length of ischium with 


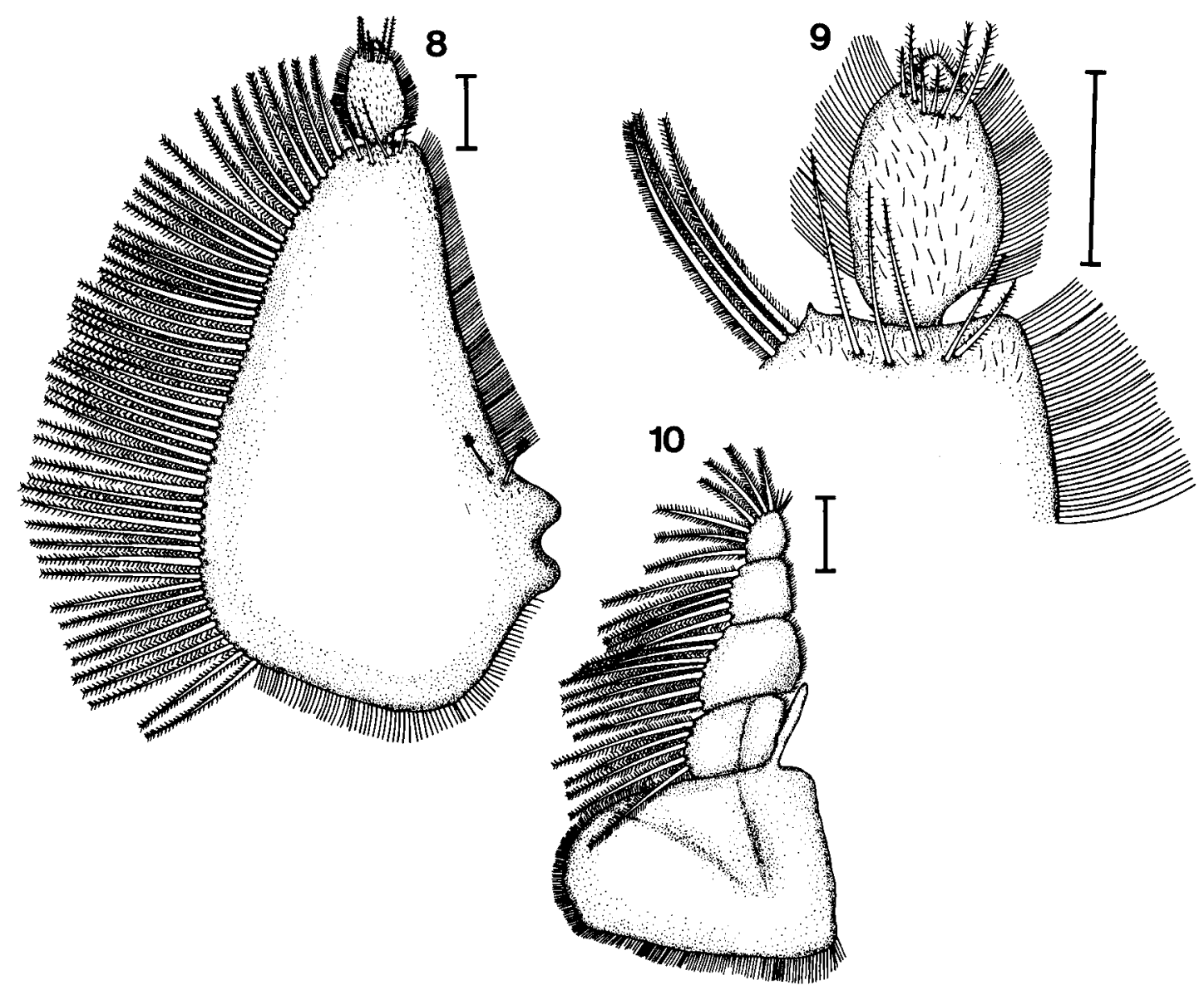

Figs. 8-10. Cephalosome appendages of a Gnathia pantherina sp. n. male (NMBP 216). Fig. 8. Pylopod. Fig. 9. Articles 2 and 3 of pylopod. Fig. 10. Maxilliped. Scale bars: Figs. 8-10=100 $\mu \mathrm{m}$.

anterior bulbous protrusion, pappose and simple setae on bulbous protrusion, posterior margin with tubercles as well as pappose setae. Carpus of almost same size and shape as merus, but without anterior bulbous and distal part of posterior margin respectively, only a few short simple setae anteriorly with one feather-like seta distally. Dactylus half the length of propodus, terminates in sharp posterior-pointing unguis, prominent protrusion, posterior margin with tooth-shaped tubercles and pappose setae. Propodus about twice the length of carpus, one tooth-shaped tubercle on proximal posterior margin, two robust denticulated setae situated on middle robust seta on posterior side proximal to unguis, few simple setae on dorsal and ventral sides of robust seta. Pereopods 3 to 6 similar in basic shape to pereopod 2 (Fig. 11), differ in setation as well as distribution of tubercles. Pereopod 4 with distinct tooth-shaped tubercles on anterior margin of basis, ischium and merus. Pereopod 6 with two robust elongated denticulated setae on posterior bulbous protrusion of merus. Dorsal surface of all pereopods covered with pectinate scales [only showed in illustration of pereopod 6 (P6), Fig. 11].
PLEOPOD. Endopod longer than exopod. Both fringed distally with five to seven short pappose setae, short simple setae on lateral and posterior margins of sympodite. Sympodite with retinaculae on medial margin. All pleopods similar, except pleopod 2 (Fig. 6) with appendix masculina on endopod, appendix masculina three quarters length of rami (Fig. 6).

UROPOD. Rami extending beyond apex of pleotelson, endopod longer and wider than exopod, both with long pappose setae, pectinate scales on lateral areas of uropods (Fig. 7). Uropodal basis covered with pectinate scales.

PENES. Prominent with two contiguous papillae, wider than long (Fig. 37).

Remarks. The specimens of $G$. pantherina collected at the two localities (De Hoop Nature Reserve and Jeffreys Bay) did not show any notable variation in body morphology, but differed in body size. Larger specimens were collected at De Hoop Nature Reserve.

The current four described species of the genus Gnathia from southern Africa can be divided into two groups, that is, species with pereonite 5 completely 


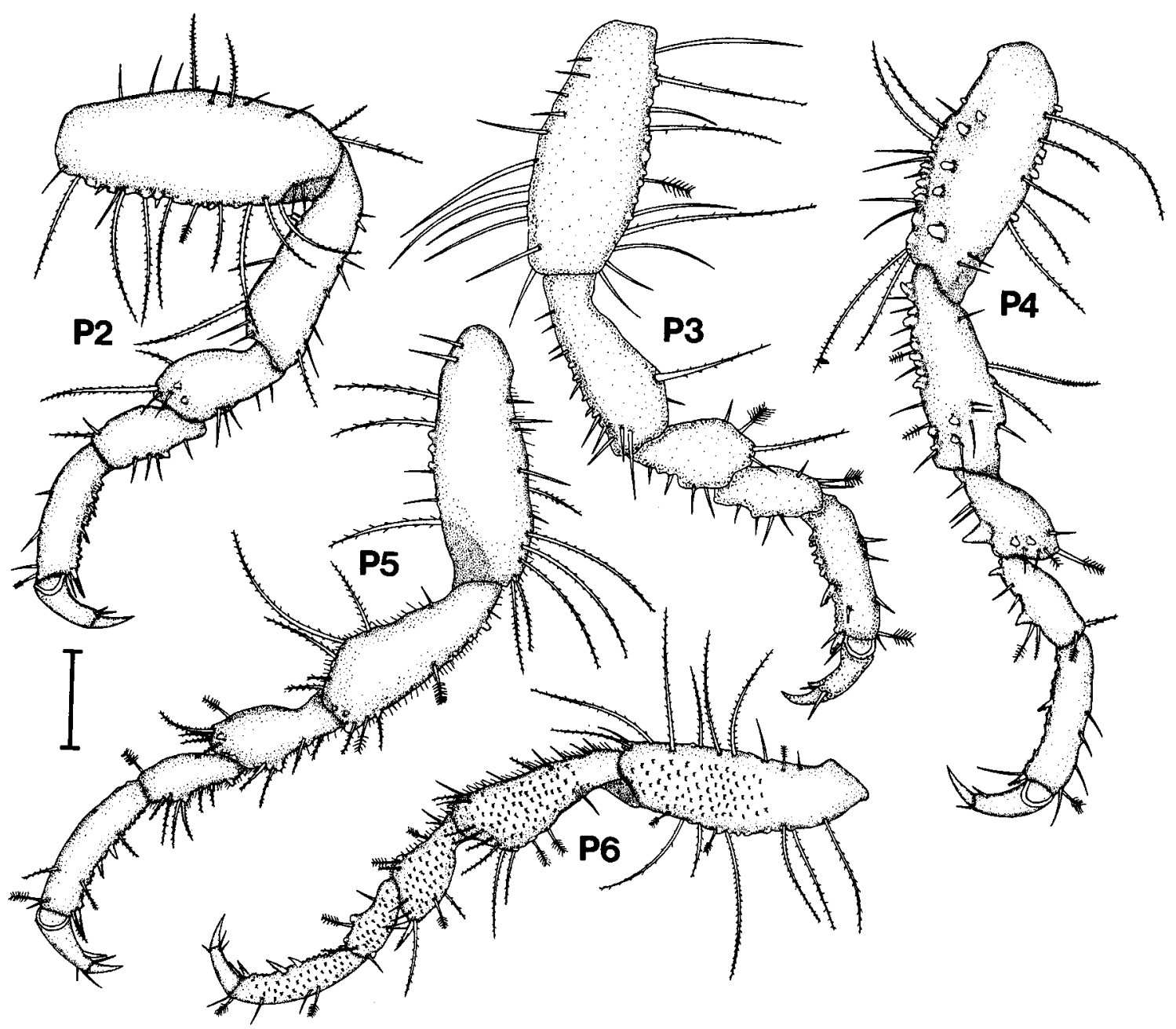

Fig. 11. Pereopods 2 to $6(\mathrm{P} 2-\mathrm{P} 6)$ of a Gnathia pantherina sp. n. male (NMBP 216). Scale bar: $=200 \mu \mathrm{m}$.

separated into two halves by pereonite 6 (Gnathia disjuncta Barnard, 1914 and G. spongicola Barnard, 1920) and those with a normal pereonite morphology (G. africana Barnard, 1914 and G. nkulu Smit et Van As, 2000) (see Barnard 1914a, 1920, Smit et al. 1999, Smit and Van As 2000). Gnathia pantherina falls into the latter group. The $G$. pantherina male can be distinguished from these two species by means of its deeply concave divided mediofrontal process and the dorsally visible lamina dentata. Both $G$. pantherina and G. nkulu have a row of long plumose setae and tubercles extending laterally from under the eyes posteriomedially almost reaching the median tubercle (see Smit and Van As 2000). Gnathia pantherina differs from $G$. $n k u l u$ in the shape of the frontal border, morphology of pylopod article 2 and the length of the appendix masculina.

The deeply concave mediofrontal process of G. pantherina is very similar to that of the Caribbean species, Gnathia beethoveni Paul et Menzies, 1971. Gnathia pantherina differs, however, from $G$. beethoveni in the shape of the pleotelson, the presence of long pappose setae on the pereon and pleon and tubercles on the pereopods. According to the original line drawing by Paul and Menzies (1971) as well as the one in the redescription of $G$. beethoveni by Müller (1989), the plumose setae on the palp articles of the maxillipedes are in the order of 3-6-5-7. This differs from the 5-7-5-7 formula of $G$. pantherina. Müller (1989) also pointed out that the antenna 1 of $G$. beethoveni terminates in two aesthetascs. In $G$. pantherina the distal three articles of antenna 1 have a single aesthetasc each. The males of G. pantherina are also much larger $(3.7-6.8 \mathrm{~mm})$ than $G$. beethoveni males ( $3 \mathrm{~mm})$.

Another species with a concave divided mediofrontal process is Gnathia margaritarum Monod, 1926 described from the Gulf of Panama. Gnathia pantherina differs from this species in the absence of a granular cephalosome and pereonites 1-3, and the presence of a characteristic row of long pappose setae and tubercles 

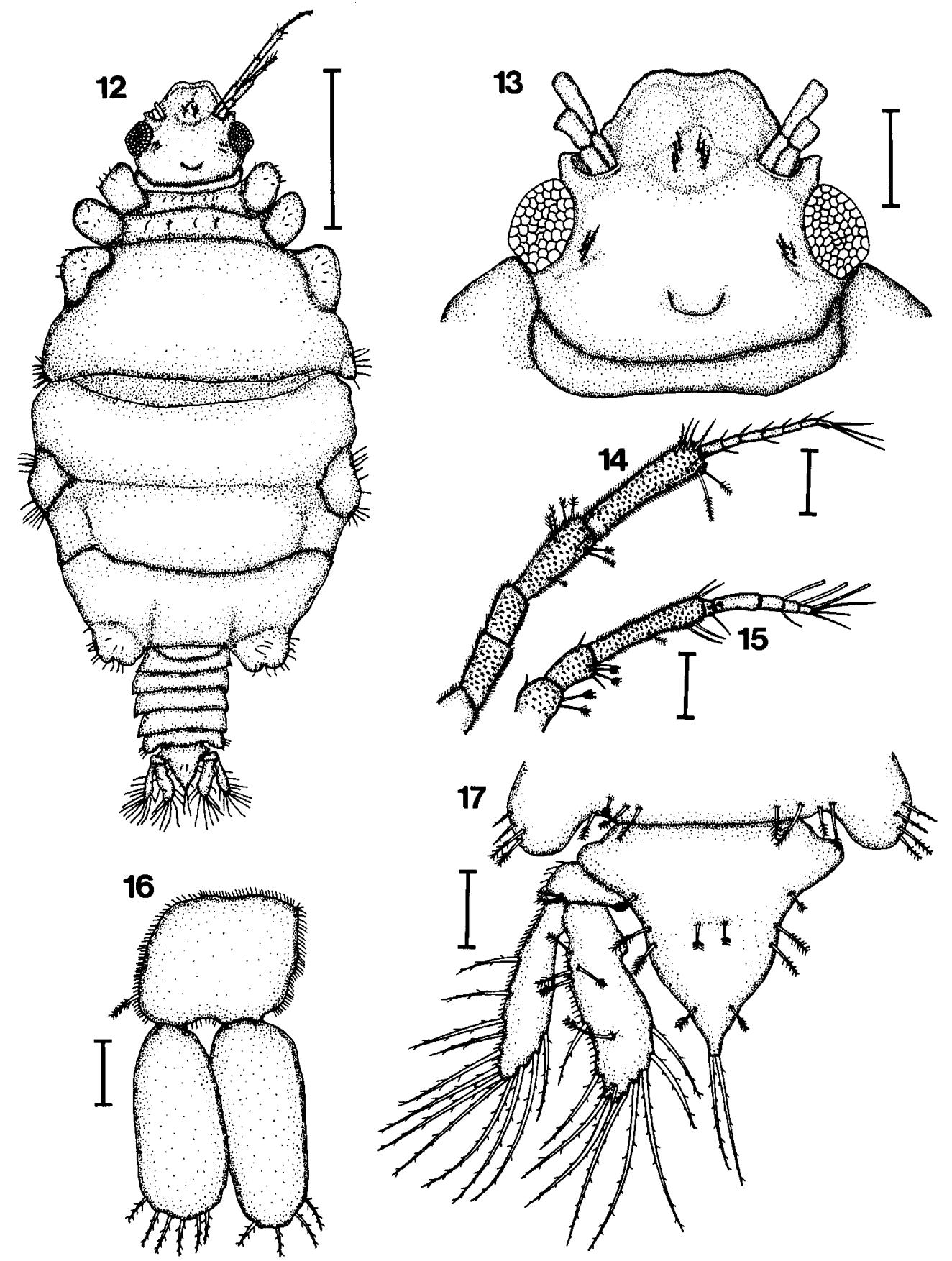

Figs. 12-17. Gnathia pantherina sp. n., female (NMBP 218). Fig. 12. Full length dorsal view. Fig. 13. Cephalosome and frontal border. Fig. 14. Second antenna. Fig. 15. First antenna. Fig. 16. Left pleopod 1. Fig. 17. Pleotelson and uropods. Scale bars: Fig. $12=1 \mathrm{~mm}$; Fig. $13=500 \mu \mathrm{m}$; Figs. $14-17=100 \mu \mathrm{m}$.

extending laterally from under the eyes posteriomedially. The plumose setae of the palp articles of $G$. margaritarum (in order of 4-5-5-6) (see Müller 1989) are also different from that of $G$. pantherina (in order of 5-7-5-7). As with G. beethoveni, G. pantherina males are also much larger that those of G. margaritarum (2.3 $\mathrm{mm})$.
The presence of a straight frontal border with frontal processes, broad 3-articled pylopods, and denticulated mandibles, supports the placement of this species in the genus Gnathia (see Cohen and Poore 1994). 

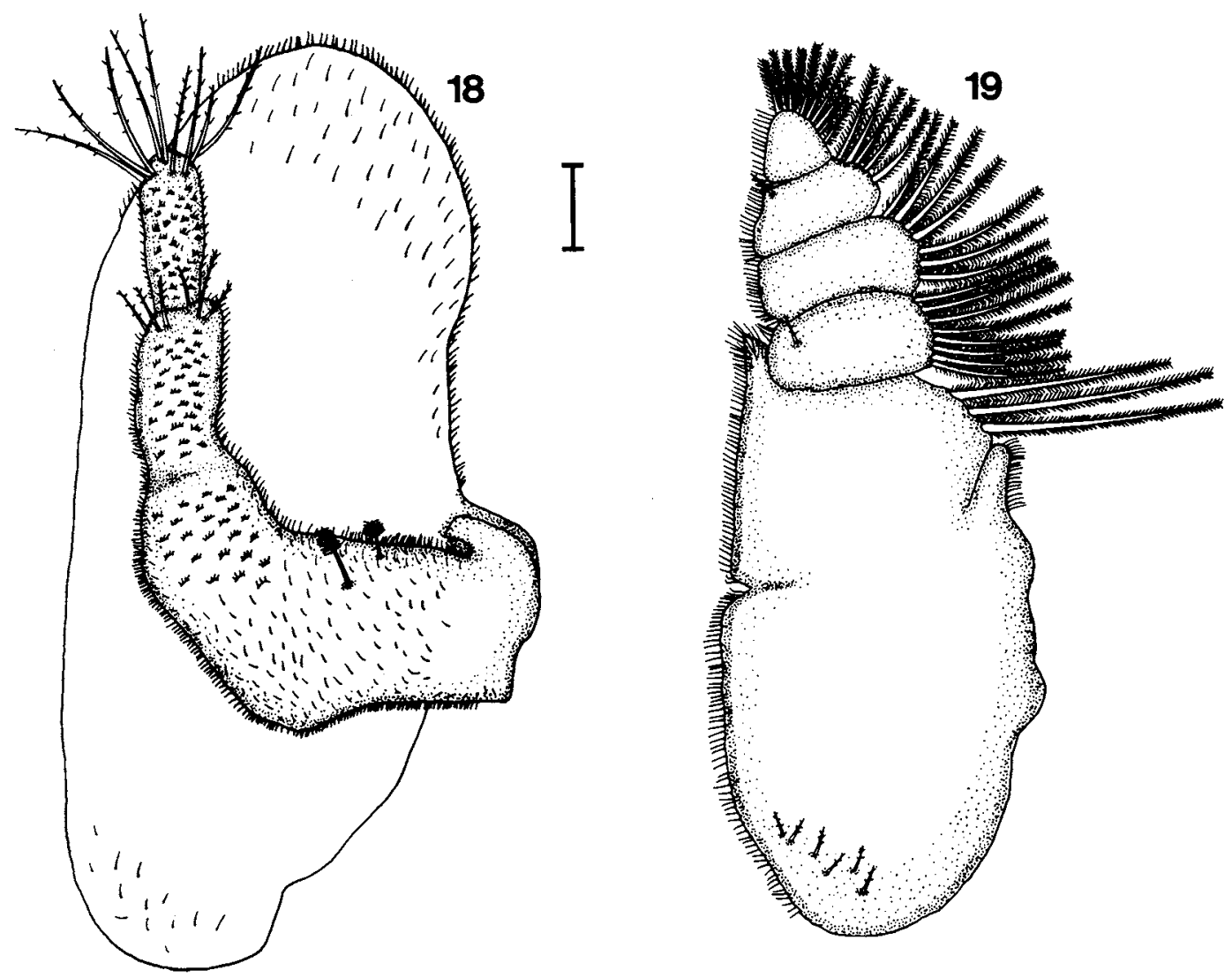

Figs. 18, 19. Cephalosome appendages of a Gnathia pantherina sp. n. female (NMBP 218). Fig. 18. Left pylopod. Fig. 19. Left maxilliped. Scale bars: Figs. 18, $19=100 \mu \mathrm{m}$.

\section{Adult female}

Figs. 12-20, 38-39

Description: Total length of paratypes: $4.3-5.1 \mathrm{~mm}$ $(4.7 \pm 0.37 \mathrm{~mm}, \mathrm{n}=7)$. Total length of other material: 3.7-6.8 mm $(5.2 \pm 0.54, \mathrm{n}=10)$.

Cephalosome. Broadened, short. Rectangular, 1.25 times as wide as long, short simple setae on dorsal, lateral and ventral cephalosome, posterior margin straight (Figs. 13, 38). Well-developed oval-shaped, bulbous, compound eyes on lateral margin of cephalosome, length of eye three quarters of cephalosome. No paraocular ornamentation, only four to six short pappose setae (Figs. 13, 38).

FRONTAL BORDER. Broadly rounded, produced, slightly concave anteriorly, with six to eight short pappose setae on mid-dorsal area (Figs. 13, 38).

ANTENNAE. Antenna 2 longer than antenna 1. Antenna 1 with three peduncle articles increasing in length distally with third article as long as first and second articles combined, few short pappose setae on distal end of articles 1 and 2 and four to seven short pappose and feather-like setae on article 3. Flagellum with five articles, article 2 largest, articles 3 and 4 with one aesthetasc seta each, article 5 terminating in a single aesthetasc and three simple setae (Fig. 15). Antenna 2 with five peduncle articles, article 4 largest, short pappose setae on distal end of articles 4 and 5, flagellum with seven articles, article 1 largest, article 7 terminating in three to four simple setae (Fig. 14). Peduncle articles of both antennae covered with very short hairlike simple setae and pectinate scales.

MANDIBLE. Absent.

PYLOPOD. Comprises three articles, articles 1 and 2 fused. Article 1 broad, robust, curved anteriorly, with two feather-like setae mid-dorsally, article 2 with five to six short pappose setae distally (Fig. 18). Article 3 with eight to ten long pappose setae distally. Oval-shaped oostegite, 2.25 times broader than long (Fig. 18), covers mouthparts ventrally, not surpassing frontal border. Posterior surface of article 2 and distal half of article 1 covered with pectinate scales and short hair-like simple setae, proximal half of article 1 and lateral borders of all articles and oostegite with short hair-like simple setae.

MAXILLIPED. Consists of a coxa with attached oostegite, basis and palp of four articles (Fig. 19). Endite short, not reaching article 2 of palp. Lateral margins of basis fringed with three long plumose setae. Palp bearing plumose setae on lateral margins in order of 8-7-5-10, article 1 and 3 of palp each with single short pappose seta anterio-dorsally (Fig. 19). Coxa with attached oostegite as broad but longer than palp. Mesial borders of basis, palp and oostegite densely setose. 


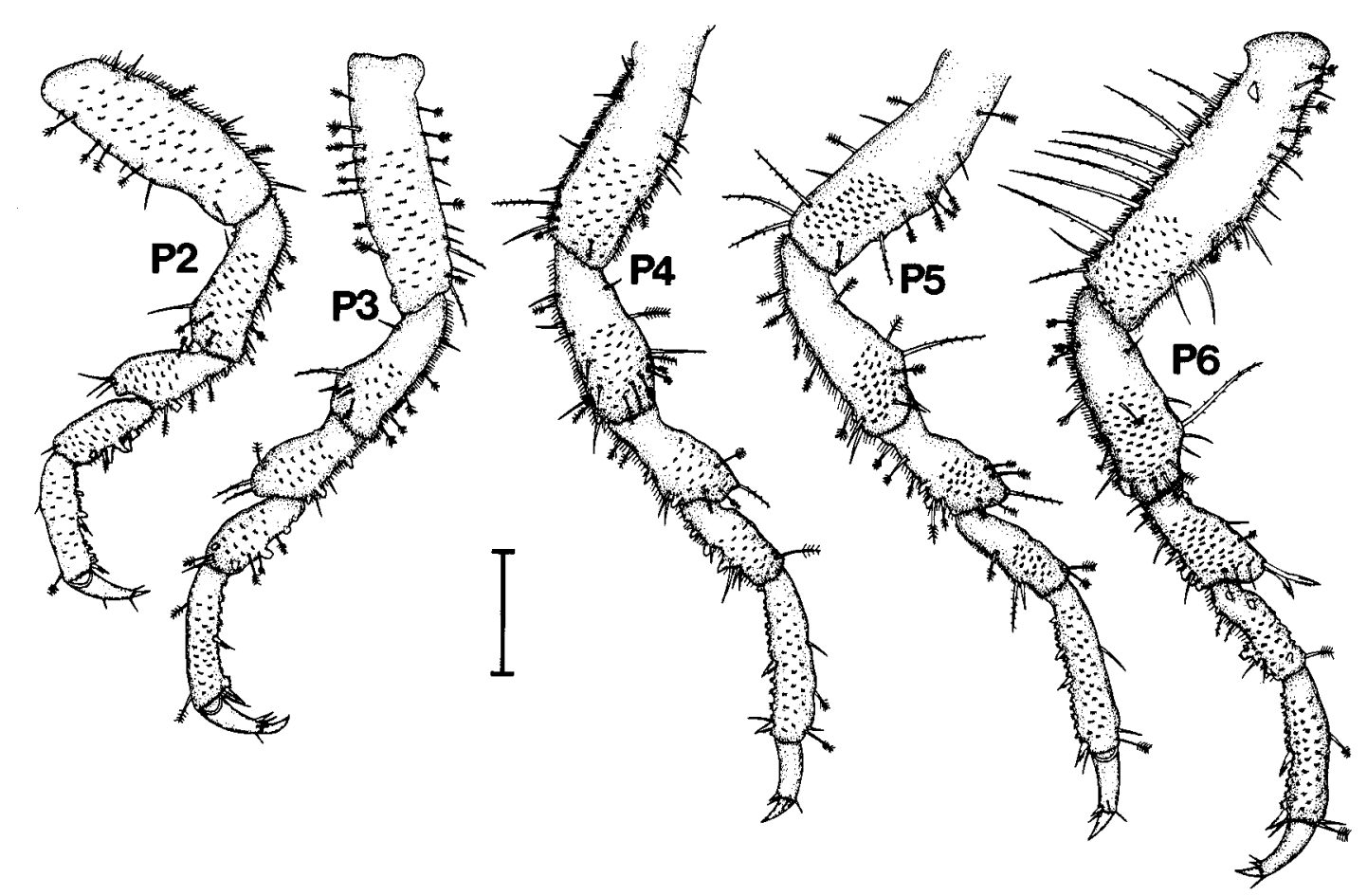

Fig. 20. Pereopods 2 to 6 (P2-P6) of a Gnathia pantherina sp. n. female (NMBP 218). Scale bar $=200 \mu \mathrm{m}$.

MAXILLA. Both maxillae 1 and 2 absent.

PEREON. Swollen round, sutures between pereonites 5-7. One and a half times as long as wide, wider than cephalosome (Fig. 12), covered with numerous long pappose setae and short simple hair-like setae. Pereonite 7 dorsally visible, small with rounded posterior margin, overlapping first pleonite (Fig. 12). Most setae on anterior and lateral margins of pereonites.

PLEON. Pleon and pleotelson less than a quarter of total length (Fig. 12). Five subequal pleonites dorsally visible, epimera not distinct, short hair-like setae and short pappose setae randomly distributed on pleonites.

PLEOTELSON. Triangular, base wider than length, lateral margins slightly concave, dorsal surface with five pairs of feather-like setae and many short simple setae and pectinate scales, distal apex terminating in pair of long pappose setae (Fig. 17).

PEREOPODS. Pereopod 2 basis elongated oval-shaped with four to six feather-like setae and simple setae anteriorly, two feather-like setae and four to eight posterior simple setae (Fig. 20). Ischium two thirds length of basis, three to five anterior feather-like setae and simple setae, posterior tubercles with three simple setae and four feather-like setae. Merus half the length of ischium with anterior bulbous protrusion, three simple setae on bulbous protrusion, posterior margin with tooth-shaped tubercles as well as feather-like setae. Carpus of almost same size and shape as merus, but without anterior bulbous protrusion, posterior margin with large tooth-shaped tubercles. Propodus about twice the length of carpus, tooth-shaped tubercle on posterior margin, two robust denticulated setae situated on middle and distal part of posterior margin respectively, single simple seta anteriorly with one feather-like seta distally. Dactylus half the length of propodus, terminates in sharp posterior-pointing unguis, robust seta on posterior side proximal to unguis, few simple setae on dorsal and ventral sides of robust seta. Posterior margin of all articles densely setose. Pereopods 3 to 6 similar to pereopod 2 in basic form, differ in setation, shape and number of tubercles (Fig. 20). Pereopod 6 with two elongated robust denticulated setae on posterior bulbous protrusion of merus. Dorsal surface of all pereopods covered with pectinate scales (Fig. 20). Coxae of pereopods 4 to 6 with thin plate-like oostegites, enclose brood pouch, oostegites overlapping (Fig. 39).

PLEOPOD. Pleopod 1 endopod longer than exopod. Both fringed distally with four to eight short pappose setae (Fig. 16). No coupling hooks visible. Sympodite without retinacula, single feather-like seta on lateral margin, all margins setose. Pleopods 2 to 5 similar to pleopod 1.

UROPOD. Rami extending beyond apex of pleotelson, endopod longer and wider than exopod, both with long pappose setae (Fig. 17), pectinate scales on anterio-lateral areas of uropods. Five feather-like setae on dorsal endopod. Uropodal basis with two feather-like setae. 



Figs. 21-26. Gnathia pantherina sp. n., praniza larva (NMBP 219). Fig. 21. Full length dorsal view. Fig. 22. Dorsal cephalosome with labrum and antennae. Fig. 23. First antenna. Fig. 24. Second antenna. Fig. 25. Left pleopod 1. Fig. 26. Pleotelson and uropods. Scale bars: Fig. $21=1 \mathrm{~mm}$; Fig. $22=500 \mu \mathrm{m}$; Figs. $23-26=100 \mu \mathrm{m}$.

Remarks. The only other female gnathiid described from South Africa is that of Gnathia africana (Barnard 1914b). Gnathia africana females collected by the authors (see Smit 2000) were examined for comparison. It was found that the rounded produced frontal border of G. pantherina females is very similar to that of $G$. africana, but in all $G$. pantherina specimens examined it appears to be slightly concave anteriorly. Gnathia pantherina females can be distinguished from $G$. africana females by the following characteristics. The lateral margins of the pleotelson of $G$. pantherina are concave and those of G. africana females are straight. The sympodite of the pleopods of $G$. pantherina females lack retinacula, found in G. africana females. The plumose setae on the lateral margins of the maxillipedal palp articles of $G$. pantherina are in the order 8-7-5-10 

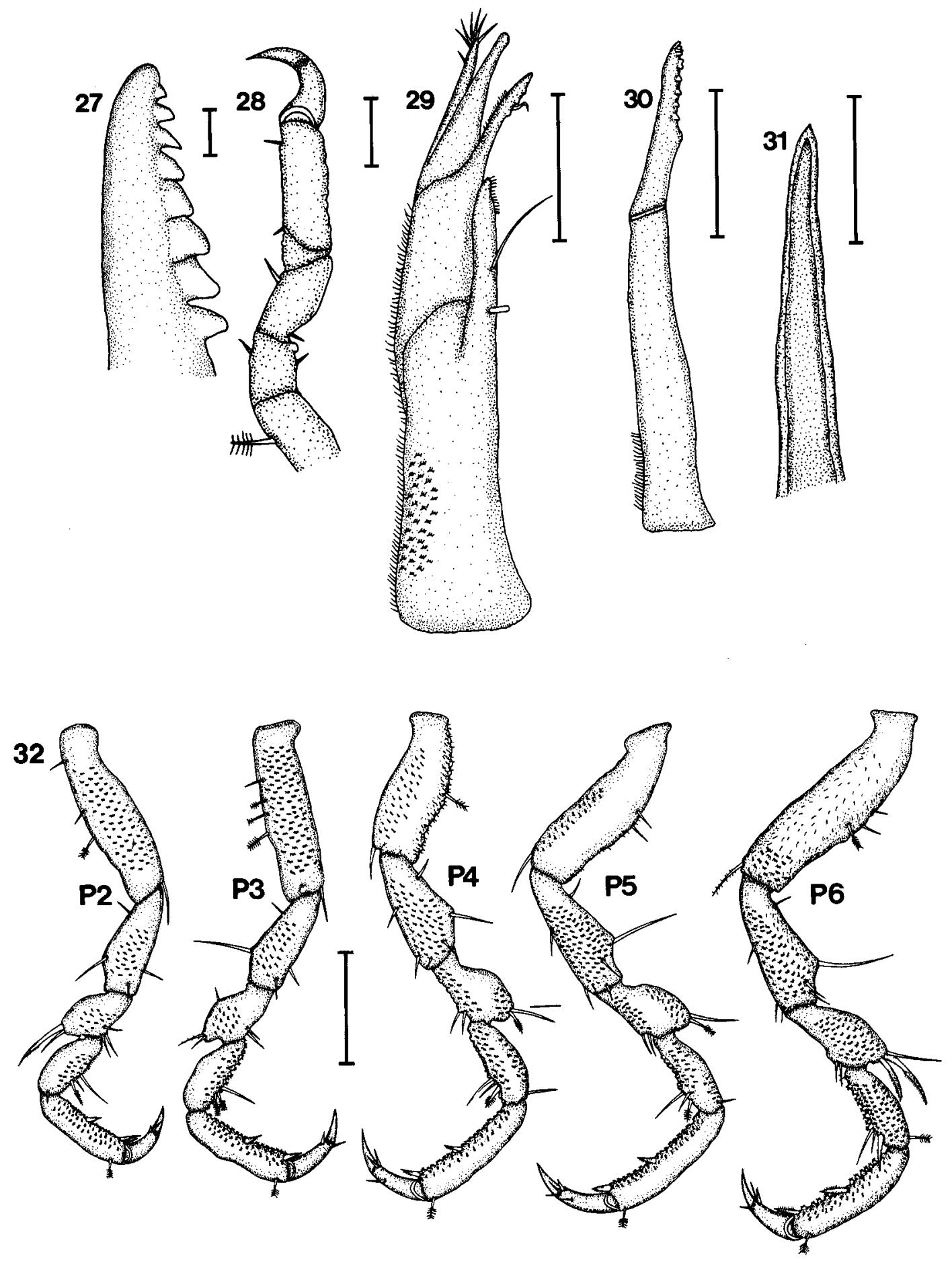

Figs. 27-31. Cephalosome appendages of a Gnathia pantherina sp. n. praniza larva (NMBP 219). Fig. 27. Mandible. Fig. 28. Gnathopod. Fig. 29. Maxilliped. Fig. 30. Maxillule. Fig. 31. Paragnath. Fig. 32. Pereopods 2 to 6 (P2-P6) of a Gnathia pantherina sp. n. praniza larva (NMBP 218). Scale bars: Fig. $27=10 \mu \mathrm{m}$; Figs. $28-31=100 \mu \mathrm{m}$; Fig. $32=200 \mu \mathrm{m}$. 
(from proximal to distal) while that of G. africana is 38-5-5. Gnathia pantherina females $(3.7-6.8 \mathrm{~mm})$ are also larger than $G$. africana females (3.2-4.3 mm).

There are unfortunately no descriptions available for the females of the two species, $G$. beethoveni and $G$. margaritarum, whose males show some similarities to the males of $G$. pantherina.

\section{Praniza larva}

Figs. 21-32, 40-43

Description: Total length of paratypes: $3.9-5.8 \mathrm{~mm}$ $(5.1 \pm 1.1 \mathrm{~mm}, \mathrm{n}=10)$. Total length of other material: 3.8-6.0 mm $(5.2 \pm 1.0 \mathrm{~mm}, \mathrm{n}=30)$

CEPHAlosome. Posterior margin straight, slightly wider than anterior margin, almost as wide as long, lateral margins slightly convex (Figs. 22, 41). Many sensory pits and three pairs of short simple setae on dorsal surface of cephalosome. Compound eyes large, well-developed, oval-shaped, bulbous, on lateral margins of cephalosome, length of eye almost same as cephalosome. No sulcusses or tubercles on dorsal cephalosome. Medio-anterior margin of cephalosome straight with lateral concave excavations to accommodate first articles of antennae.

LABRUM. Prominent, half the length of cephalosome, semicircular with apical process, truncated posterior margin, anterior margin concave (Figs. 22, 41). Ventral part of labrum gutter-like with central groove, covers mandibles dorsally and laterally.

ANTENNAE. Antenna 2 longer than antenna 1. Antenna 1 with three peduncle articles, a pair of featherlike setae on articles 1 and 2 respectively, article 3 largest with short hair-like setae and pectinate scales on anterior border. Flagellum with four articles, first article with two to three short simple setae mid-dorsally, article 2 largest, articles 2 and 3 with one aesthetasc seta each, article 4 terminating in one aesthetasc and three simple setae, few setae on each article (Fig. 23). Antenna 2 with four peduncle articles, article 4 largest, flagellum with seven articles, article 7 terminating in three to four simple setae, few setae on distal end of each article (Fig. 24).

MANDIBLE. Stout, swollen at base, distal margin styliform with eight teeth on mesial margin, two small teeth situated at tip of mandible, six larger, triangular and backwardly directed, increasing in size from anterior to posterior (Figs. 27, 43).

GNATHOPOD. Smaller than pereopods, seven articles, single feather-like seta on basis, only few simple setae on other articles (Figs. 28, 42). Dactylus strongly hooked.

MAXILLIPED. Large, cylindrical, elongated base with pectinate scales and short hair-like setae laterally, endite almost reaching palp with single long simple seta coupling hook (Figs. 29, 42). Palp with three articles, first article acute with three to five small teeth and a single simple seta mesially, articles 3 with five to seven simple setae (Fig. 29).

MAXILlAE. Not visible.
MAXILlulE. Long, slender (Fig. 43), swollen base, stretching past distal margin of labrum. Seven small teeth on distal inner margin (Fig. 30).

PARAGNATHS. Elongated, gutter-like, terminate in sharp point, no teeth (Figs. 31, 43).

PEREON. Almost twice as long as wide, wider than cephalosome (Fig. 21). Pereonite 1 fused with cephalosome, dorsally visible (Fig. 41). Pereonite 2 with anterior constriction separating it medianly from pereonite 1 . Pereonite 4 twice as wide as long, lateral sides tapering towards rounded posterior margin, posterior margin stretching over pereonite 5 (Fig. 21), lateral shields at leg attachment. Pereonite 5 consists of elastic membrane fully expanded in praniza stage with blood meal (Fig. 40), bulbous shields present on lateral sides at leg attachment. Pereonite 6 rectangular, posterior margin slightly concave, lateral shields at leg attachment. Pereonite 7 dorsally visible, small with rounded posterior margin, overlapping first pleonite (Fig. 21). Sensory pits randomly distributed over all pereonites.

PLEON. Pleon and pleotelson slightly half the length of pereon. Five pleonites dorsally visible (Fig. 21). Single simple seta, on each posterior lateral side of each pleonite.

PLEOPOD. Pleopod 1 endopod larger than exopod. Both fringed distally with seven to nine long plumose setae, short hair-like setae on all margins (Fig. 25). Sympodite with retinacula, single simple seta on lateral margin and short hair-like setae on dorsal surface and margins. Pleopods 2 to 5 similar to pleopod 1.

PleOtELSON. Triangular, longer than wide, anterior half of lateral margins slightly concave, posterior half straight, a pair of simple setae on posterior dorsal surface, distal apex terminating in pair of simple setae, dorsal surface covered with pectinate scales (Fig. 26).

UROPOD. Endopod extending beyond apex of pleotelson, exopod reaching apex. Endopod longer and wider than exopod, both with long fringing setae, endopod with mesial six plumose setae, exopod with mesial four plumose setae, rest of setae simple (Fig. 26). Lateral dorsal areas of both endo- and exopods with pectinate scales, all margins with short hair-like setae. Uropodal basis with two simple setae.

PEREOPODS. Pereopod 2 basis elongated with single feather-like bristle and two to four simple setae anteriorly, single simple seta posteriorly (Fig. 32). Ischium three quarters length of basis and almost as wide, two to four anterior setae and two to three posterior. Merus half the length of ischium with anterior bulbous protrusion, single elongated denticulated seta and single simple seta on bulbous protrusion, posterior margin with simple setae. Carpus of almost same size and shape as merus, but without anterior bulbous, tubercles and single feather-like seta on posterior margin. Propodus about twice the length of carpus, two robust denticulated seta situated on middle and distal 


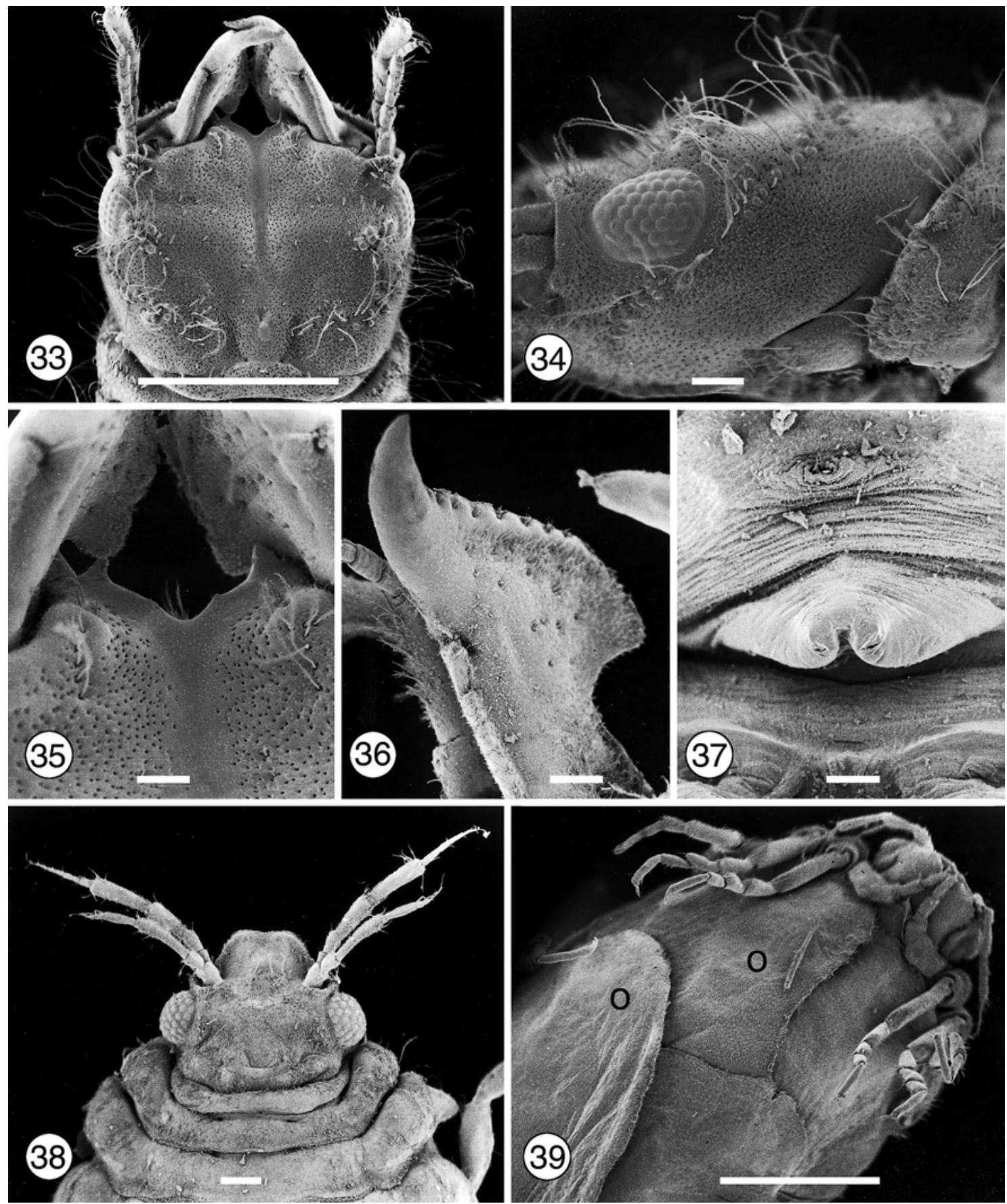

Figs. 33-39. Gnathia pantherina sp. n., male (Figs. 33-37) and female (Figs. 38, 39), scanning electron micrographs. Fig. 33. Dorsal view of male cephalosome. Fig. 34. Lateral view of male cephalosome. Fig. 35. Dorsal view of male frontal border. Fig. 36. Dorsal view of left mandible of male. Fig. 37. Ventral view of penes. Fig. 38. Dorsal view of female cephalosome and pereonites 1-3. Fig. 39. Ventral view of female pereon with plate-like oostegites (o) Scale bars: Figs. 33, $39=1$ mm; Figs. 34-38 $=100 \mu \mathrm{m}$.

part of posterior side respectively, only a few simple setae anteriorly with single feather-like seta anteriodistally. Dactylus half the length of propodus, terminates in sharp posterior-pointing unguis, prominent robust seta on posterior side proximal to unguis, two to three simple setae on dorsal and ventral sides of robust seta. Pereopods 3 to 6 (Fig. 32), similar to pereopod 2 in basic form, differ in setation. Pereopods 3 to 5 without elongated denticulated seta, pereopod 6 with two elongated denticulated setae on bulbous protrusion of 

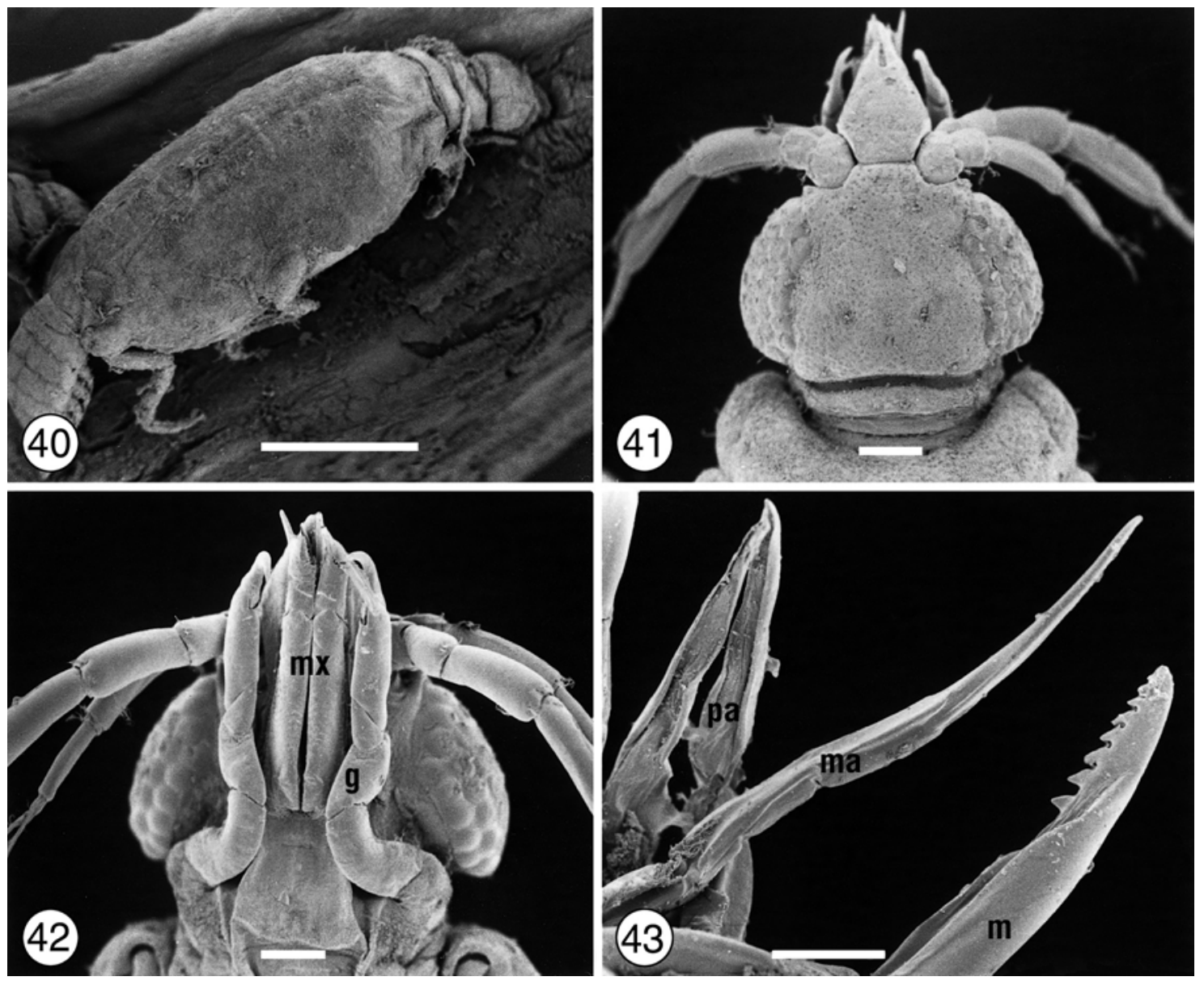

Figs. 40-43. Gnathia pantherina sp. n., praniza larva, scanning electron micrographs. Fig. 40. Praniza larva attached to the gill septum of Haploblepharus edwardsii. Fig. 41. Dorsal view of cephalosome. Fig. 42. Ventral view of cephalosome with gnathopods (g) and maxillipedes (mx). Fig. 43. Paragnaths (pa), maxillule (ma) and mandible (m). Scale bars: Fig. $40=1 \mathrm{~mm}$; Figs. $41-43=100 \mu \mathrm{m}$.

merus and a single one on anterior margin of carpus. Pereopods 2 and 3 direct posteriorly and pereopods 4 to 6 anteriorly. All articles of pereopods with pectinate scales and short hair-like setae (Fig. 32).

$\mathrm{T}$ y p e $\mathrm{m}$ a t e r i a 1 : Holotype: In the collection of the National Museum, Bloemfontein (1 male, NMBP 216). Paratypes: In the collection of the National Museum, Bloemfontein, South Africa (4 males, NMBP 217; 4 females, NMBP 218 and 7 praniza larvae, NMBP 219), in the collection of the South African Museum, Cape Town (1 male, SAM A43573; 2 females, SAM A44176; 2 praniza larvae, SAM A44177) and in the collection of the Institute of Parasitology, ASCR, České Budějovice, Czech Republic (1 male, 1 female, 1 praniza larva, PaÚ AV ČR No. 1986).

T y p e 1 o c a 1 i t y : Jeffreys Bay (34⒉2'S, $\left.24^{\circ} 56.5^{\prime} \mathrm{E}\right)$.

O t h e r 1 o c a 1 i t i e s : De Hoop Nature Reserve $\left(34^{\circ} 28^{\prime} \mathrm{S}\right.$, $\left.20^{\circ} 30^{\prime} \mathrm{E}\right)$.

Hos t s of $\mathrm{par}$ a s i t c 1 a r va e : Poroderma pantherinum (Smith, 1838) (type host), Haploblepharus edwardsii (Voight, 1832) and Torpedo fuscomaculata Peters, 1855.

$\mathrm{O} \mathrm{th}$ e $\mathrm{r} \mathrm{m}$ a t e $\mathrm{r}$ i a $1:$ In the collection of the authors (13 males, 10 females, 30 praniza larvae).

E $\mathrm{t} \mathrm{y} \mathrm{m} \mathrm{o} l \mathrm{og} \mathrm{y}$ : The species name is derived from the feminine form of the specific name of the type host Poroderma pantherinum.

Remarks. No morphological differences were found between the zuphea and praniza stages, except that in the praniza stages the elastic membrane between pereonites 3 and 6 was fully stretched due to the presence of the blood meal in the anterior hindgut (Fig. 40). As in the case of gnathiid females, few comprehensive descriptions of gnathiid larvae exist. Of the South African species, a detailed description of only the larvae of $G$. africana is available (see Smit et al. 1999). Other comprehensive descriptions have been done for the larvae of Gnathia maxillaris (Montagu, 1804) by Davies (1981), Caecognathia calva (Vanhöffen, 1914) by 
Wägele (1987), Paragnathia formica by Charmantier et al. (1987), Euneognathia gigas (Beddard, 1886) by Brandt and Wägele (1991), and Caecognathia bicolor (Hansen, 1916) by Svavarsson (1999).

The basic morphology of $G$. pantherina larvae is very similar to that of $G$. africana larvae. Gnathia pantherina can, however, be distinguished from G. africana by the following morphological characteristics. The pleotelson of $G$. pantherina larvae have concave anterio-lateral margins in comparison to the straight margins of those of $G$. africana larvae. The mandibles of $G$. africana have 9 to 10 teeth on the mesial margin, in comparison to the eight teeth of $G$. pantherina. The first palp article of the maxilliped of $G$. africana has five to seven teeth distally and $G$. pantherina three to five small teeth distally. The maxillipedal endite of $G$. africana lacks the coupling hook, which is present in $G$. pantherina. Praniza 3 larvae of $G$. pantherina are also much larger than those of $G$. africana.

The pleotelson of $G$. pantherina larvae is very similar to that of G. maxillaris. Although it appears, from the electron micrograph published by Davies (1981), to be rather slightly broader than long, in comparison to the longer than broad pleotelson of $G$. pantherina. The pereon and pleon of $G$. maxillaris larvae are also covered with pectinate scales in comparison to the smooth surface of $G$. pantherina. Gnathia maxillaris mandibles have twelve teeth, with the maxillules and the first article of the maxillipedal palp bearing nine teeth respectively. This differs from $G$. pantherina, which has mandibles with eight, maxillules with seven and a maxillipedal palp with three to five teeth. The endite of the maxilliped of $G$. maxillaris does not possess a coupling hook.

The slightly longer than broad pleotelson of $G$. pantherina larvae differs considerably from that of Caecognathia calva larvae. The lateral margins of the pleotelson of $C$. calva larvae are concave and the pleotelson is almost twice as long as broad with the uropods not surpassing the apex of the pleotelson (see Wägele 1987). The mandibles of both these species have eight teeth, while the maxillule of $C$. calva has eight compared to the seven of $G$. pantherina. The endite of the maxilliped of C. calva surpasses the insertion of the palpal endites, whereas in G. pantherina, the endite only reaches the palp.

The larvae of $G$. pantherina can easily be distinguished from those of Paragnathia formica by the number of flagellum articles of antenna 2. Gnathia pantherina has seven flagellum articles and $P$. formica nine (Charmantier et al. 1987). These two species also differ considerably in the number of the mandible teeth. Those of $P$. formica have 12 or 13 teeth, compared to $G$. pantherina, which only has eight. The gnathopods of $P$. formica larvae bear a small tooth near the base of the dactylus, a characteristic which is absent in $G$. pantherina. The first article of the maxillipedal palp of $P$. formica has 11 or 12 teeth compared to 3 to 5 of $G$. pantherina. When comparing $G$. pantherina larvae to the larvae of another genus, Euneognathia gigas, the most distinct difference is again the shape of the pleotelson. The pleotelson of E. gigas larvae is narrow and more than twice as long as wide, with the uropods also not surpassing the pleotelson apex (Brandt and Wägele 1991). In $G$. pantherina the pleotelson is slightly longer than broad with the endopod of the uropods surpassing the apex of the pleotelson. Of all these species $G$. pantherina can most easily be distinguished from the larvae of Caecognathia bicolor since the larvae of $C$. bicolor do not possess eyes and the flagellum of their antenna 2 consists of only six articles (Svavarsson 1999).

Acknowledgements. The authors thank Prof. Angela Davies Russell, Kingston University, UK, for reading the draft copy. This study was funded by the marine resource program of the National Research Foundation (NRF) of South Africa.

\section{REFERENCES}

BARNARD K.H. 1914a: Contributions to the crustacean fauna of South Africa. 1. Additions to the marine Isopoda. Ann. S. Afr. Mus. 10: 197-230.

BARNARD K.H. 1914b: Contributions to the crustacean fauna of South Africa. 3. Additions to the marine Isopoda, with notes on some previously incompletely known species. Ann. S. Afr. Mus. 10: 325a-358a, 359-442.

BARNARD K.H. 1920: Contributions to the crustacean fauna of South Africa. 6. Further additions to the list of marine Isopoda. Ann. S. Afr. Mus. 17: 319-438.

BARNARD K.H. 1926: Contributions to the Crustacean fauna of South Africa. 9. Further additions to the list of Isopoda. Ann. S. Afr. Mus. 20: 381-411.

BRANDT A., WÄGELE W. 1991: Parasitic Isopoda of the family Gnathiidae from the Atlantic sector of the Southern Ocean. Redescriptions and remarks on the synonymy (Crustacea: Isopoda). Senckenb. Marit. 21: 233-261.
CHARMANTIER G., EUZET S., DAVIES A.J. 1987: A scanning electron microscope study of Paragnathia formica (Hesse, 1864) (Isopoda, Gnathiidae), with special reference to the mouthparts of larvae and males. Crustaceana 53: 134-147.

COHEN B.F., POORE G.C.B. 1994: Phylogeny and biogeography of the Gnathiidae (Crustacea: Isopoda) with descriptions of new genera and species, most from southeastern Australia. Mem. Mus. Victoria 54: 271-397.

DAVIES A.J. 1981: A scanning electron microscope study of the praniza larva of Gnathia maxillaris Montagu (Crustacea, Isopoda, Gnathiidae), with special reference to mouthparts. J. Nat. Hist. 15: 545-554.

GRUTTER A.S., POULIN R. 1998: Intraspecific and interspecific relationships between host size and the abundance of parasitic larval gnathiid isopods on coral reef fishes. Mar. Ecol. Prog. Ser. 164: 263-271. 
HEUPEL M.R., BENNETT M.B. 1999: The occurrence, distribution and pathology associated with gnathiid isopod larvae infecting the epaulette shark, Hemiscyllium ocellatum. Int. J. Parasitol. 29: 321-330.

HONMA Y., CHIBA A. 1991: Pathological changes in the branchial chamber wall of stingrays, Dasyatis spp., associated with the presence of juvenile gnathiids (Isopoda, Crustacea). Gyobyo Kenkyu 26: 9-16.

HONMA Y., TSUNAKI S., CHIBA A., HO J-S. 1991: Histological studies on juvenile gnathiid (Isopoda, Crustacea) parasitic on the branchial chamber wall of the stingray Dasyatis akajei, in the sea of Japan. Rep. Sado Mar. Biol. Stn. 21: 37-47.

MONOD T. 1926: Les Gnathiidae. Essai monographique (Morphologie, Biologie, Systématique). Mem. Soc. Sci. Nat. Maroc 13: 1-668.

MÜLLER H.G. 1989: Two new species of Gnathia Leach from coral reefs at Moorea, Society Islands, with redescription of Gnathia margaritarum Monod, 1926 from Panama Pacific (Isopoda: Cymothoidea: Gnathiidae). Bull. Zool. Mus. 12: 65-78.

PAPERNA I., POR F.D. 1977: Preliminary data on the Gnathiidae (Isopoda) of the Northern Red Sea, the Bitter Lakes and the Eastern Mediterranean and the biology of Gnathia piscivora n. sp. Rapp. P.-v. Réun. Commn. Int. Explor. Scient. Mer Méditerr. 24: 195-197.

PAUL A.Z., MENZIES R.J. 1971: Sub-tidal isopods of the Fosa de Cariaco, Venezuela, with descriptions of two new genera and twelve new species. Bol. Inst. Oceanogr. Univ. Oriente 10: 29-48.

SMIT N.J. 2000: The biology of gnathiid isopod parasites and their role as vectors of fish blood parasites in South Africa. $\mathrm{PhD}$ thesis, University of the Orange Free State, Bloemfontein, $250 \mathrm{pp}$.

SMIT N.J., BASSON L., VAN AS J.G. 2000: A redescription of the adult male of Caecognathia cryptopais (Barnard, 1925) (Crustacea: Isopoda: Gnathiidae) from southern Africa. Folia Parasitol. 47: 61-66.

SMIT N.J., VAN AS J.G. 2000: A new species, Gnathia nkulu sp. n. (Crustacea: Isopoda: Gnathiidae) from southern Africa. Folia Parasitol. 47: 235-240.

SMIT N.J., VAN AS J.G., BASSON L. 1999: A redescription of the adult male and praniza of Gnathia africana Barnard, 1914 (Crustacea, Isopoda, Gnathiidae) from southern Africa. Folia Parasitol. 46: 229-240.

SMITH M., HEEMSTRA P.C. 1986: Smith's Sea Fishes. Macmillan South Africa, Johannesburg, 1047 pp.

SVAVARSSON J. 1999: The deep water gnathiid Caecognathia bicolor (Hansen, 1916) (Crustacea, Isopoda, Gnathiidae) - redescription and new data on its distribution. Rit. Fiskideild. 16: 171-185.

WÄGELE J.W. 1987: Description of the postembryonal stages of the Antarctic fish parasite Gnathia calva Vanhöffen (Crustacea: Isopoda) and synonymy with Heterognathia Amar \& Roman. Polar Biol. 7: 77-92. 